\title{
Assessment of an Aging of Protective Decorative
}

\section{Coatings}

\begin{abstract}
Valentina Ivanovna Loganina
Department of Quality management and technology of building production, «Penza State University of Architecture and Construction», Penza, Russia

Ludmila Viktorovna Makarova

Department of Quality management and technology of building production, «Penza State University of Architecture and Construction», Penza, Russia

\section{Svetlana Nikolaevna Kislitsyna}

Department of Technology of construction materials and woodworking, «Penza State University of Architecture and Construction», Penza, Russia

Copyright (C) 2014 Valentina Ivanovna Loganina, Ludmila Viktorovna Makarova and Svetlana Nikolaevna Kislitsyna. This is an open access article distributed under the Creative Commons Attribution License, which permits unrestricted use, distribution, and reproduction in any medium, provided the original work is properly cited.
\end{abstract}

\begin{abstract}
Information about a technique of an assessment of resistance of protective decorative coatings is provided. The method is based on an assessment of physicsmechanical properties and processing of facsimiles of coatings surface.
\end{abstract}

Keywords: varnish coatings, aging, whiteness of coatings, coefficient of intensity of tension

\section{Introduction}

Along with traditional methods of an assessment of resistance of protective decorative coatings the development and application of new techniques allows to receive information about aging processes comprehensively.

In accordance with the normative literature weathering protective and decorative coatings express life, defines the visual degree of loss of protective and 
decorative properties under the influence of the destruction caused by weathering, while resistance of the coating is measured at the point system. However, this assessment is often subjective [1].

\section{Experimental study}

For an assessment of resistance of coatings during their aging we applied the graphic editor Adobe Photoshop [2]. During an aging under the influence of moisture and other factors there is a change of a roughness of a coatings surface, colors, etc. that, undoubtedly, leads to change of a ratio of color at processing of facsimiles of a coatings surface. At influence of environment a violation of continuity of a coatings surface is possibly, i.e. emergence of cracking, that has to increase a share of black color at an image assessment. However, along with change of the protective properties also there is a change of decorative ones, namely, emergence of bloom, a bronzing, mud-deduction. These factors in total lead to change of a ratio of black and light colors of facsimiles of a coatings surface. Thus, work with a graphic image will allow to give a comparative assessment of coatings resistance during an aging along with physics-mechanical tests.

During the work with the facsimile the range of brightness 0-121 was attributed to black, and 122-255 - to white. Pictures of a coatings surface were scanned in the "black-and-white" photo mode with the same values of brightness, contrast, dpi, etc. Each picture is opened with the same scale equal to $25 \%$.

Additionally, for an assessment of resistance of protective decorative coatings the method of an assessment of tendency to crack formation based on a ratio between the crack length, a print of an Vikkers's indenter and viscosity of destruction was applied [3]. The critical coefficient of intensity of tension was determined by a formula

$$
K_{1 c}=0,028 H a^{0,5}(E / H)^{0,5}(C / a),
$$

where $\mathrm{H}-$ Vikkers's hardness;

$\mathrm{C}$ - semi-length of radial cracks;

a -semi-length of diagonal print.

\section{Results and discussion}

Influence of technological factors, namely, humidity and porosity of a substrate, on coatings resistance was investigated. As colourful compositions in work oil MA-15,MA-115, the alkyd PF-268, PF-115, PF-266 water dispersion acrylate paints were applied. Colourful compositions were applied on mortar substrates with various humidity and the surface porosity in two layers with the 
intermediate drying for 20-30 minutes. After curing of coatings the painted mortar exemplars were located in water. During carrying out of tests also the whiteness assessment with glossmeter was carried out. Results of researches are given in tables $1,2$.

Table 1: Parameters of crack formation of protective decorative coatings

\begin{tabular}{|c|c|c|c|c|}
\hline $\begin{array}{c}\text { Kind of } \\
\text { colourful } \\
\text { composition }\end{array}$ & $\begin{array}{c}\text { Humidity of } \\
\text { a substrate, } \\
\%\end{array}$ & $\begin{array}{l}\text { Porosity of a } \\
\text { substrate, } \%\end{array}$ & Loading, $\mathrm{H}$ & $\begin{array}{c}\text { Coefficient of } \\
\text { intensity of } \\
\text { tension, } \\
\mathrm{K}_{1 \mathrm{c}}, \mathrm{MH} / \mathrm{m}^{1,5}\end{array}$ \\
\hline 1 & 2 & 3 & & 5 \\
\hline Alkyd PF-115 & $\begin{array}{c}0 \\
0 \\
0 \\
10,5\end{array}$ & $\begin{array}{c}0,13 \\
0,9 \\
10,5 \\
6,4\end{array}$ & 25,39 & $\begin{array}{l}0,0379 \\
0,0379 \\
0,0256 \\
0,0404\end{array}$ \\
\hline Alkyd PF-268 & $\begin{array}{c}0 \\
0 \\
0 \\
10,4\end{array}$ & $\begin{array}{c}0,13 \\
0,9 \\
10,5 \\
6,4\end{array}$ & & $\begin{array}{c}0,0554 \\
0,0554 \\
0,048 \\
0,054\end{array}$ \\
\hline MA-15 & $\begin{array}{c}0 \\
0 \\
9,9\end{array}$ & $\begin{array}{c}0,33 \\
6,4 \\
6,4\end{array}$ & & $\begin{array}{c}0,0257 \\
0,02147 \\
\text { peeling }\end{array}$ \\
\hline
\end{tabular}

It was established that in coatings "embrittlement" happens after particular time of humidification. So, cracks in coatings at cave-in of an Vikkers's indenter appear on a coating PF-266 on a substrate with the surface porosity Ps $=0 \%$ and on a substrate with the surface porosity Ps $=6,2 \%$ and humidity at the time of drawing colourful composition $9,9 \%$. For coatings MA-115 on a substrate with Ps $=6,7 \%$ and humidity at the time of drawing the paint $\mathrm{W}=10,2 \%$ the coating peeling after 2 months of humidification is characteristic. 
Table 2: Results of processing of facsimiles of a surface of protective decorative coatings

\begin{tabular}{|c|c|c|c|c|}
\hline $\begin{array}{l}\text { Kind of colourful } \\
\text { composition }\end{array}$ & $\begin{array}{c}\text { Humidity } \\
\text { of a } \\
\text { substrate, } \\
\%\end{array}$ & $\begin{array}{c}\text { Porosity of } \\
\text { a substrate, } \\
\%\end{array}$ & $\begin{array}{c}\text { Whiteness } \\
\text { after } 2 \text { months } \\
\text { of } \\
\text { humidification, } \\
\%\end{array}$ & $\begin{array}{c}\text { The area } \\
\text { occupied with } \\
\text { light color, \% }\end{array}$ \\
\hline 1 & 2 & 3 & & 4 \\
\hline $\begin{array}{l}\text { Alkyd PF-115 } \\
\text { (color blue) }\end{array}$ & $\begin{array}{c}0 \\
0 \\
10,4 \\
9,4 \\
0\end{array}$ & $\begin{array}{c}0,13 \\
0,9 \\
6,4 \\
6,7 \\
6,7\end{array}$ & $\begin{array}{l}59 \\
59 \\
52 \\
58 \\
-\end{array}$ & $\begin{array}{l}0,07 / 98,91 \\
0,07 / 99,62 \\
0,08 / 98,64 \\
0,08 / 99,46 \\
0,08 / 99,52\end{array}$ \\
\hline $\begin{array}{l}\text { Alkyd PF -268 } \\
\text { (color brown) }\end{array}$ & $\begin{array}{c}0 \\
0 \\
10,4\end{array}$ & $\begin{array}{c}0,13 \\
0,9 \\
6,4\end{array}$ & $\begin{array}{l}51 \\
54 \\
53\end{array}$ & $\begin{array}{l}0,01 / 3,19 \\
0,01 / 1,49 \\
0,02 / 2,37\end{array}$ \\
\hline $\begin{array}{l}\text { Oil MA-115 } \\
\text { (color white) }\end{array}$ & $\begin{array}{c}0 \\
10,2\end{array}$ & $\begin{array}{c}0,33 \\
6,7\end{array}$ & $\begin{array}{c}- \\
80\end{array}$ & $\begin{array}{l}99,31 / 99,04 \\
98,98 / 99,54\end{array}$ \\
\hline $\begin{array}{l}\text { Water dispersion } \\
\text { acrylate (color } \\
\text { white) }\end{array}$ & $\begin{array}{c}0 \\
3,6\end{array}$ & $\begin{array}{l}1,18 \\
1,18\end{array}$ & $\begin{array}{l}85 \\
85\end{array}$ & $\begin{array}{l}95,72 / 99,46 \\
99,38 / 99,98\end{array}$ \\
\hline
\end{tabular}

Note. In numerator values of the space occupied by the light color on the facsimile of a surface after curing of coatings are indicated, in a denominator - after an aging.

The analysis of the experimental data provided in table 1 testifies that with increase of surface porosity of a substrate to a particular limit the decrease of coefficient of intensity of tension is observed. So, at loading $\mathrm{P}=25,39 \mathrm{H}$ the value of coefficient of intensity of tension Ks for a coating PF-115 on a substrate with surface porosity $\mathrm{Ps}=0,13-1,2 \%$ after 2 months of humidification makes $\mathrm{Ks}=0,0376 \mathrm{MH} / \mathrm{m}^{1,5}$, and on a substrate with surface porosity $\mathrm{Ps}=10,5 \%-0,0256$ $\mathrm{MH} / \mathrm{m} 1,5$; and for a coating MA-15 values of coefficient of intensity of tension respectively make $0,0257 \mathrm{MH} / \mathrm{m}^{1,5}$ and $0,02147 \mathrm{MH} / \mathrm{m}^{1,5}$. Apparently, it is bound to that pores on a substrate surface to some extent as if "extinguish" internal tensions and reduce a tendency to crack formation of coatings

The increase of humidity of a substrate at the time of drawing colourful composition leads to emergence of more defect structure of a contact layer "coating-substrate" and larger tendency to a crack formation. The coefficient of intensity of tension for coatings PF-115 at humidity of a substrate at the time of drawing colourful composition, equal $\mathrm{W}=10,4 \%$ after 2 months of humidification makes $\mathrm{Ks}=0,404 \mathrm{MH} / \mathrm{m}^{1,5}$. 
The given above results of researches well correlate with the data obtained during a scanning (table 2). Results of scanning show that after humidification the space occupied by light spots increases. For coatings PF-115 the sharp increase of the space occupied by the light color is characteristic irrespective of porosity and humidity of a substrate at the time of drawing colourful composition. So after curing the space occupied by the light color makes $0,06-0,07 \%$, and after two months of humidification - 98,64-99,62\%. Coatings based on the alkyd enamel PF-268 more resistant to action of humidification, they are characterized by not so considerable discoloration.

\section{Conclusion}

The data provided in tables 1, 2 testify that at this stage of an aging, generally the change of decorative properties occurs apparently. Cracking of coatings at this stage does not happen.

Thus, the complex approach to an assessment of resistance of coatings will allow to estimate endurance of a protective decorative coatings more objective.

\section{References}

[1] V. I. Loganina, L. P. Orentlikher. Resistance of a protective decorative coatings of external walls of buildings. M.:izd-in ABU. 2001.

[2] A. N. Dyuryagina, A. V. Demyanenko, K. N. Bolatbayev. Application of the graphic editor Adobe Photoshop for determination of coatings continuity. The Production coloring. No.4. 2003. 30 p.

[3] V. I. Loganina, L. V. Makarova. To a technique of an assessment of crack resistance of protective and decorative coatings. Plasts. No.4. 2003. P 43-44.

Received: November 17, 2014; Published: December 23, 2014 